\title{
Increase in Zucchini yellow mosaic virus Symptom Severity in Tolerant Zucchini Cultivars Is Related to a Point Mutation in P3 Protein and Is Associated with a Loss of Relative Fitness on Susceptible Plants
}

\author{
C. Desbiez, A. Gal-On, M. Girard, C. Wipf-Scheibel, and H. Lecoq
}

INRA, Station de Pathologie Végétale, Domaine Saint Maurice, BP94, 84143 Montfavet, France; second author: ARO, Volcani Center, BetDagan, Israel.

Accepted for publication 17 June 2003.

\begin{abstract}
Desbiez, C., Gal-On, A., Girard, M., Wipf-Scheibel, C., and Lecoq, H. 2003. Increase in Zucchini yellow mosaic virus symptom severity in tolerant zucchini cultivars is related to a point mutation in $\mathrm{P} 3$ protein and is associated with a loss of relative fitness on susceptible plants. Phytopathology 93:1478-1484.

Zucchini yellow mosaic virus (ZYMV, Potyvirus) is a very damaging cucurbit virus worldwide. Interspecific crosses with resistant Cucurbita moschata have led to the release of "resistant" zucchini squash (C. pepo) $\mathrm{F}_{1}$ hybrids. However, although the resistance is almost complete in $C$. moschata, the commercial $C$. pepo hybrids are only tolerant. ZYMV evolution toward increased aggressiveness on tolerant hybrids was observed in the field and was obtained experimentally. Sequence com-

parisons and recombination experiments revealed that a point mutation in the $\mathrm{P} 3$ protein of $\mathrm{ZYMV}$ was enough to induce tolerance breaking. Competition experiments were performed between quasi-isogenic wildtype, and aggressive variants of ZYMV distinguished by monoclonal antibodies. The aggressive mutants were more fit than wild-type strains in mixed infections of tolerant zucchini, but they presented a drastic fitness loss in mixed infections of susceptible zucchini or melon. Thus, the ability to induce severe symptoms in tolerant zucchini is related to a genetic load in susceptible zucchini, but also on other susceptible hosts. This represents the first quantitative study of the fitness cost associated with tolerance breaking for a plant virus. Thus, although easily broken, the tolerance might prove durable in some conditions if the aggressive variants are counterselected in susceptible crops.
\end{abstract}

Zucchini yellow mosaic virus (ZYMV, Potyvirus) causes important damage in cucurbit crops worldwide and, like many other RNA viruses, it presents an important biological variability (24). Breeding for durable resistance is regarded as one of the most promising approaches to control ZYMV. Resistance or tolerance to ZYMV is known in most cultivated cucurbit species, including melon, cucumber, and zucchini squash (8). Resistance to ZYMV in Cucurbita moschata cv. Menina is related to a major dominant gene, Zym-1, associated with at least two complementary genes, Zym-2 and Zym-3 (30). Resistance in C. moschata cv. Nigeria local also was described as rather complex, possibly involving one major factor plus some modifiers (29). ZYMV resistance has been introduced in zucchini squash (C. pepo) commercial hybrids through interspecific crosses (33). ZYMV induces only mild symptoms on "resistant" commercial hybrids: systemic chlorotic spots or mild mottle, with occasionally more severe mosaic patches in restricted leaf areas. However, systemic virus multiplication does occur; therefore, these plants should be considered as tolerant rather than resistant (25).

After the release of resistant commercial cultivars, an evolution of virus populations may sometimes be observed leading to a breakdown of the resistance. Although several studies have analyzed the genetic determinants involved in Potyvirus resistance breaking (31), very little is known regarding tolerance and its durability. Resistance or tolerance durability is related to two factors: (i) the frequency of appearance of adapted variants in the plants, which is itself a consequence of the mutation rate of the virus and of the mechanism interfering with the plant-virus

Corresponding author: C. Desbiez; E-mail address: desbiez@avignon.inra.fr

Publication no. P-2003-0929-03R

(C) 2003 The American Phytopathological Society interaction, and (ii) the fitness of such variants in susceptible or resistant plants (22). If the fitness cost for resistance breaking is very high, evolved variants may not be able to emerge or persist in virus populations, and a resistance apparently easily overcome in greenhouse conditions might prove to be durable in the field.

In this study, we established that an increased aggressiveness of ZYMV on tolerant zucchini squash, defined as the ability to induce severe symptoms, is due to a single point mutation in the P3 protein, and we showed that, although aggressive mutants are as fit as wild-type strains in single infection in tolerant or susceptible cultivars, they present an important loss of relative fitness in mixed infections in susceptible hosts.

\section{MATERIALS AND METHODS}

Host plants and virus inoculations. The following commercial zucchini squash (C. pepo) cultivars were used: ZYMV-susceptible $F_{1}$ Diamant and ZYMV-tolerant Afrodite, Dividend, Sofia, Jaguar, and Tigress. The susceptible melon (Cucumis melo L.) cv. Védrantais also was used. Mechanical inoculations were conducted according to our standard procedure: leaves from infected plants were triturated in $0.03 \mathrm{M} \mathrm{Na}_{2} \mathrm{HPO}_{4}$ containing $0.2 \%$ Na-diethyldithiocarbamate (DIECA) (1:5, wt/vol) with a mortar and pestle. Extracted juice was mixed with 400-mesh Carborundum $(75 \mathrm{mg} / \mathrm{ml})$ and activated charcoal $(75 \mathrm{mg} / \mathrm{ml})$ before being rub-inoculated on zucchini squash or melon test plants. Aphid transmission experiments were performed using Myzus persicae. Aviruliferous aphids were starved for 1 to $2 \mathrm{~h}$ before being allowed a 1- to 2-min acquisition access period on infected leaves. Aphids then were deposited by groups of five on test plants for a 2-h inoculation access period. Test plants then were sprayed with an insecticide before being transferred to an insectproof greenhouse. Symptoms were noted 3 weeks later. 
Virus strains and variants. ZYMV strains E9 and E15 are reference strains from southeastern and southwestern France, respectively, that induce severe symptoms on zucchini Diamant, but that present some differences in symptomatology on melon Doublon (23). Strains MT92-1, MT97-177, and MT97-183 were collected on Martinique Island in 1992 and 1997, respectively $(9,10)$. ZYMV-NAT, originating from Israel, is a very severe non-aphidtransmissible strain that reaches particularly high titers in infected plants (2,13). ZYMV-R5A and ZYMV-Mau originate from Réunion Island and Mauritius, respectively, and are highly divergent from the type strain at the molecular level (10). ZYMV-IT73, ZYMV-1318, and ZYMV-MF-Dia00, were collected between 1973 and 2000 from fields of susceptible cucurbits, while isolates ZYMV-MF-Afro00, Valence01, Italy01, and Jordan01 were collected in 2000 and 2001 in France, Italy, and Jordan, respectively, from fields of tolerant zucchini squash cultivars presenting severe symptoms.

ZYMV mutants $\mathrm{A}$ and $\mathrm{B}$ were obtained previously by sitedirected mutagenesis in an infectious cDNA of ZYMV-NAT (7, 12). Mutants A and B each differ from NAT by one point mutation in the N-terminal part of the coat protein without detectable effect on virus infectivity. This mutation allows a specific serological recognition by monoclonal antibodies (MAbs) CC11 and DD2, respectively (7). Variants $\mathrm{A}^{*}$ and $\mathrm{B}^{*}$ were obtained from $\mathrm{A}$ and $\mathrm{B}$, respectively, by serial mechanical inoculations on Afrodite in greenhouse conditions. Variants of E9, E15, NAT, MT92-1, MT97-177, and MT97-183 inducing severe symptoms on tolerant cultivars also were obtained by serial inoculations on Afrodite. The same protocol was applied for E15 and NAT only, on tolerant cvs. Dividend, Sofia, Jaguar, and Tigress.

All ZYMV mutants, strains, or isolates that do not cause severe symptoms on tolerant zucchini squash will be referred thereafter as "wild-type" and those inducing severe mosaic and leaf and fruit deformations will be referred as "aggressive variants". Wild-type strains, including A and B, were propagated on Diamant, while the aggressive variants $\mathrm{A}^{*}$ and $\mathrm{B}^{*}$ were propagated on Afrodite.

Sequencing of ZYMV variant $B^{*}$. Variant ZYMV-B* was submitted to two single-local-lesion transfers on Chenopodium amaranticolor and Chenopodium quinoa before being back inoculated to Afrodite. Total RNA was extracted from one Afrodite plant showing severe symptoms. Fresh leaf tissue $(50 \mathrm{mg})$ was used for extraction with TRI-Reagent (Molecular Research Center, Cincinnati, $\mathrm{OH}$ ) according to the manufacturer's manual, and the RNA was resuspended in $20 \mu$ of diethylpyrocarbonate-treated $\mathrm{H}_{2} \mathrm{O}$. Reverse transcription (RT) and polymerase chain reaction (PCR) were performed with the Enhanced Avian RT-PCR kit (SigmaAldrich, Saint Quentin Fallavier, France). Seven pairs of primers were designed according to the nucleotide sequences of ZYMVNAT (A. Gal-On, unpublished data) and ZYMV-C (GenBank Accession No. L31350), in order to amplify the whole genome of ZYMV-B* in seven partially overlapping fragments of $\approx 1.5 \mathrm{~kb}$. The PCR products were sent for direct sequencing to Genome Express (38944 Meylan, France), using the oligonucleotides used for RT-PCR as well as internal oligonucleotides when required.

Sequencing the P3 coding region. For $26 \mathrm{ZYMV}$ isolates, including 10 pairs of wild-type strain per aggressive variant, total RNA was extracted with TRI-reagent. A fragment overlapping part of the P3 coding region was amplified by RT-PCR as above, with oligonucleotides ZYMV-1500-5' (5'-CAAGACGAATTGGACTTAGC-3', corresponding to nucleotides 1,507 to 1,526 on sequence L31350) and ZYMV-3100-3' (5'-ACAAGTTCCGACGAGAGCC-3', nucleotides 3,124 to 3,142 on sequence L31350), yielding a 1,635-bp fragment that was partially sequenced with primer ZYMV-3100-3'.

Alignments of nucleotide and amino acid sequences were performed with DAMBE (39). Sequences of ZYMV strains available from databases were added to the analysis: strains from California (ZYMV-C, L31350), Florida (ZYMV-F, L35590), Singa- pore (ZYMV-S, AF014811), Reunion (ZYMV-R, L29569), and Taiwan (ZYMV-TW-TN3, AF435425).

Construction and analysis of recombinant viruses. A 1,635-bp DNA fragment was obtained after RT-PCR performed with primers 1500-5' and 3100-3' on Afrodite plants infected with $A^{*}$ and $\mathrm{B}^{*}$, respectively. The fragments were digested with BamHI and NruI that cut at positions 2,279 and 3,095, respectively, in the genome of ZYMV-B* and ZYMV-C. The 816-bp fragment obtained after digestion was excised from an agarose gel, purified with Qiaquick gel extraction kit (Qiagen, Courtaboeuf, France), and replaced in the full-length cDNA clone of strains A and B (7). The ligation products were transformed into Escherichia coli strain XL1-Blue, and plasmid DNA was extracted by alkaline lysis. The plasmids were inoculated with a Hand Gun according to Gal-On et al. $(14,15)$ to ZYMV-susceptible Diamant plants at the cotyledonary stage. After symptom development ( $\approx 2$ weeks later), the recombinants were mechanically inoculated to Afrodite and Diamant. Symptoms were checked visually, and a 1,635-bp DNA fragment was amplified, as above, from the infected Afrodite plants 2 weeks after inoculation, and partially sequenced with primer ZYMV-3100-3' in order to confirm the presence of the $\mathrm{A}^{*}$ and $\mathrm{B}^{*}$ mutations.

Sequence comparison with P3 protein of other potyviruses. The amino acid sequences representing the P3 protein of 19 different potyviruses were aligned with the ClustalW algorithm included in DAMBE. Protein sequences from SWISSPROT included in the analysis were: Bean common mosaic virus (BCMV, Q65399), Bean yellow mosaic virus (BYMV, BAA12099), Lettuce mosaic virus (LMV-0, P31999), Maize dwarf mosaic virus (MDMV, CAA04929), Papaya ringspot virus (PRSV-HA, Q01901), Pea seedborne mosaic virus (PSbMV, P29152), Peanut mottle virus (PeMoV, O56075), Peanut stunt virus (PSV, AAB01025), Pepper mottle virus (PepMoV, Q01500), Plum pox virus (PPV-D, P13529), Potato virus A (PVA, CAB58240), Potato virus $Y$ (PVYHU, Q02963), Soybean mosaic virus (SMV, Q90069), Sweetpotato feathery mottle virus (SPFMV, BAA22702), Tobacco etch virus (TEV, P04517), Tobacco vein mottling virus (TVMV, P09814), Turnip mosaic virus (TuMV-Q, Q02597), Yam mosaic virus (YMV, ACC55549), and ZYMV (ZYMV-C, AAA65559; ZYMV-B*, AY188994). Protein secondary structure prediction was performed with Jpred consensus method (6).

Comparison of the relative fitness of wild-type and aggressive ZYMV mutants. ZYMV mutants A and B and their aggressive variants $A^{*}$ and $B^{*}$ were inoculated either singly or in mixtures of $\mathrm{A}$ and $\mathrm{B}^{*}$ or $\mathrm{A}^{*}$ and $\mathrm{B}$. For mixed inoculations, samples infected with each mutant or variant were ground independently, then the extracts were mixed in a 1:1 ratio and used for inoculation as for single infections, knowing from previous studies that there was no significant difference in virus accumulation for the different strains in the source plants (7). Five plants were inoculated for each treatment, and the experiment was repeated five times independently on zucchini and three times on melon. Inoculated plants were kept in insect-proof greenhouses for 4 weeks after inoculation.

Serological tests were performed 14 and 28 days after mechanical inoculation. A young leaf from each infected plant was ground $1: 10(\mathrm{wt} / \mathrm{vol})$ in phosphate solution, and similar extracts were prepared from healthy plants. Infected plant extracts and their 1:10 dilutions in healthy plant extracts were used for semiquantitative enzyme-linked immunosorbent assay (ELISA) tests (3). Tripleantibody sandwich (TAS)-ELISA tests were performed following the standard protocol used in the laboratory, with three MAbs: CE11, which reacts with all strains and mutants, and DD2 and CC11, which detect specifically the mutants A (and $A^{*}$ ) or B (and $\mathrm{B}^{*}$ ), respectively (7). A double-antibody sandwich (DAS)-ELISA test with a polyclonal antiserum also was performed as a control. The ELISA tests included purified virus preparations at known concentrations. Mutants A and B were purified according to a standard 
protocol used in the laboratory $(8,23)$ and stored at $-20^{\circ} \mathrm{C}$ in $50 \%$ glycerol. Purified preparations were used for ELISA in a series of twofold dilutions in healthy zucchini squash extract, ranging from $16 \mu \mathrm{g} / \mathrm{ml}$ to $15.6 \mathrm{ng} / \mathrm{ml}$. Readings at $405 \mathrm{~nm}$ were performed at different times in order to remain in the concentration-absorbance linearity domain of the reader (3). Analyses of variance (ANOVA) using Tukey's HSD test were performed with STATISTICA (StatSoft Inc., Tulsa, OK).

For comparison of the multiplication rates of various ZYMV strains or isolates in susceptible or tolerant cultivars, ELISA tests were performed with a polyclonal antiserum and with MAb CE11 only. The absorbances measured in susceptible or tolerant cultivars were compared using Student's bilateral $t$ test.

Nucleotide sequence accession numbers. All the ZYMV sequences related to this work have been submitted to GenBank. The complete sequence of ZYMV-B* was given accession number AY188994, and the partial sequences of the P3 coding region were given accession numbers AY189002 through AY189026.

\section{RESULTS}

Aggressiveness of ZYMV on tolerant zucchini squash cultivars. Tolerant zucchini squash cultivars (e.g., Afrodite and Jaguar; Fig. 1) infected with wild-type ZYMV mutants, strains, or isolates (NAT, MT92-1, MT97-177, MT97-183, A, B, E9, and E15) developed, during the first 2 to 4 weeks following inoculation, very mild symptoms limited to a few systemic chlorotic spots or a light mottle on the leaves, without symptoms on fruit. In contrast, the same ZYMV mutants, strains, or isolates induced severe symptoms of leaf mosaic, and leaf and fruit deformations and discolorations, on susceptible cultivars (e.g., Diamant; Fig. 1). Semiquantitative ELISA tests revealed that, with ZYMV isolates MT97-177, ZYMV-E9, and ZYMV-R5A, a significantly $(P<$
0.01) reduced virus accumulation was observed in Afrodite compared with the susceptible cultivar Diamant (Table 1); whereas, with ZYMV-NAT and ZYMV-E15, no significant difference was observed $(P>0.05)$. Thus, although the "resistant" plants showed only moderate symptoms, virus multiplication and spread were not suppressed, and the lack of symptoms can be related to a tolerance rather than to a complete resistance.

However, after 4 to 8 weeks of infection, restricted leaf areas with yellow to light-green mosaic symptoms frequently were observed in tolerant cultivars. When these symptomatic areas were used for one to three serial mechanical inoculation of tolerant cultivars, severe symptoms were observed on leaves and fruit of the tolerant cultivars, very similar to those observed on the susceptible cv. Diamant (Fig. 1). A similar evolution of the symptom intensity was observed when aphids were used for plant-to-plant inoculation. In a series of four replicates using Afrodite plants infected by ZYMV-E15, 95\% of the Afrodite plants inoculated by viruliferous aphids that had probed on yellow mosaic patches developed severe symptoms. In contrast, only $47 \%$ developed severe

TABLE 1. Accumulation, measured as the absorbance at $405 \mathrm{~nm}$ in doubleantibody sandwich enzyme-linked immunosorbent assay, of wild-type Zucchini yellow mosaic virus strains in susceptible (Diamant) and tolerant (Afrodite) zucchini cultivars

\begin{tabular}{lccc}
\hline & \multicolumn{2}{c}{ Absorbance $($ mean \pm SD) on } & \\
\cline { 2 - 3 } Strain & Diamant & Afrodite & $P^{\mathrm{a}}$ \\
\hline E15 & $1.04 \pm 0.11$ & $0.98 \pm 0.23$ & 0.62 \\
E9 & $1.82 \pm 0.21$ & $1.28 \pm 0.25$ & 0.01 \\
MT97-177 & $1.35 \pm 0.12$ & $0.70 \pm 0.13$ & 0.00 \\
NAT & $1.81 \pm 0.09$ & $1.83 \pm 0.13$ & 0.77 \\
R5A & $0.83 \pm 0.07$ & $0.41 \pm 0.13$ & 0.00 \\
\hline
\end{tabular}

a $P$ value (Student's bilateral test, $n=5$ ).

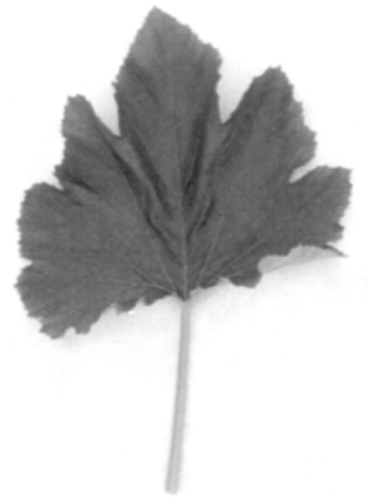

$\mathrm{H}$

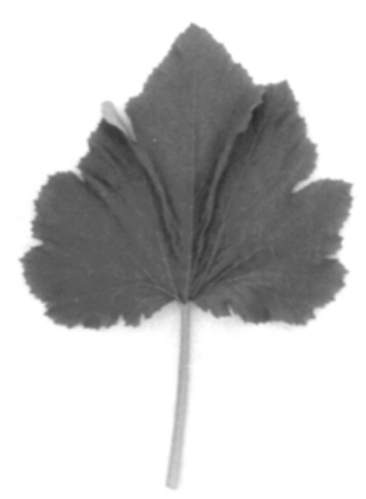

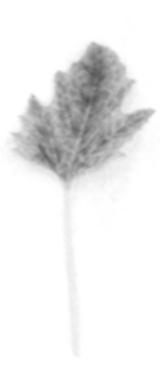

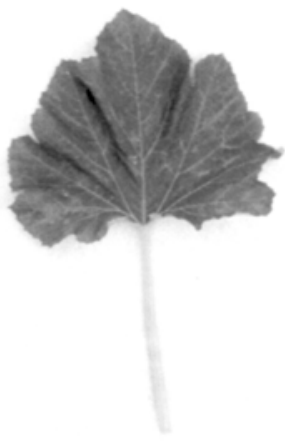

Diamant

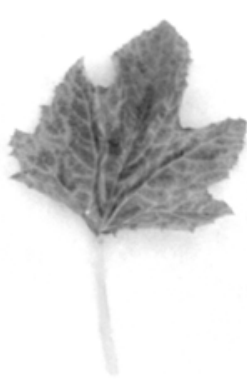

Afrodite

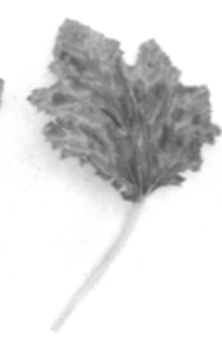

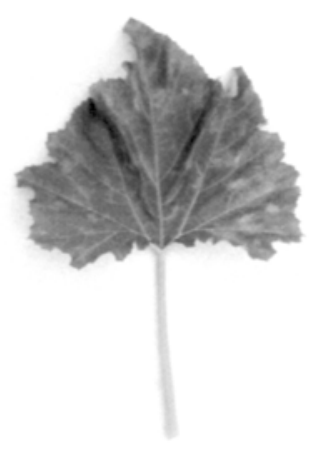

Jaguar

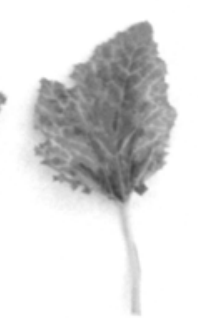

\section{Strain B}

\section{Strain $\mathrm{B}^{*}$}

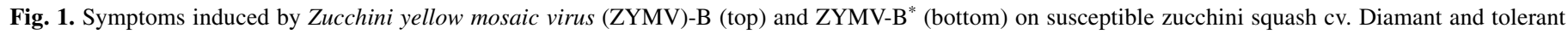
cvs. Afrodite and Jaguar. H, healthy control. 
symptoms after inoculation by viruliferous aphids that had probed on green parts of the leaves. No Afrodite plant developed severe symptoms when the aphids had probed on susceptible cv. Diamant.

The aggressive variants thus obtained were biologically isolated through single local lesion transfers on Chenopodium amaranticolor and Chenopodium quinoa, and conserved the same biological and serological properties (data not shown). Interestingly, the aggressive variants did not induce severe symptoms or invade systemically the $C$. moschata Nigeria and Menina, indicating that these land races possess additional resistance factors not present in the tolerant $C$. pepo.

Molecular determinants of aggressiveness. The complete nucleotide sequence of ZYMV-B ${ }^{*}$-aggressive variant derived from strain B-was obtained (GenBank Accession No. AY188994) and compared with a sequence of ZYMV-NAT (A. Gal-On, unpublished data), as well as to the three ZYMV full-length sequences available in databases.

Only one difference at the amino acid level was found between the sequences of NAT and $\mathrm{B}^{*}$, excluding the point mutation formerly introduced in the capsid protein of B (7). The mutation was an Arginine to Tryptophan (R to W, AGG to TGG at the nucleotide level) replacement at amino acid position 917, located in the P3 coding protein (Fig. 2).

The same region was sequenced for pairs of wild-type strain or aggressive variant obtained by serial mechanical inoculations on tolerant cultivars as well as for field isolates collected on either susceptible or tolerant cultivars (GenBank accessions AY189002 to AY189026). Sequence alignments, including ZYMV sequences available in the databases, are presented in Figure 2. All wild-type strains had an Arginine at position 917, encoded by an AGG, AGA, or CGG codon, while all aggressive variants had another amino acid at this position. The $\mathrm{R}_{917}$ to $\mathrm{W}$ mutation was the only difference in the 600-nucleotide sequenced fragment between pairs of wild-type or aggressive variants NAT/NAT*, A/A*, MT97177/MT97-177*, E9/E9*, MT97-183/MT97-183*, MT92-1/MT92$1^{*}$, and E15/E15*. In the highly divergent strains ZYMV-R5A and ZYMV-Mau, a change of $\mathrm{R}_{917}(\mathrm{AGA})$ to Asparagine $(\mathrm{N})$, encoded by an AAT or AAC codon, was observed repeatedly in four inde-

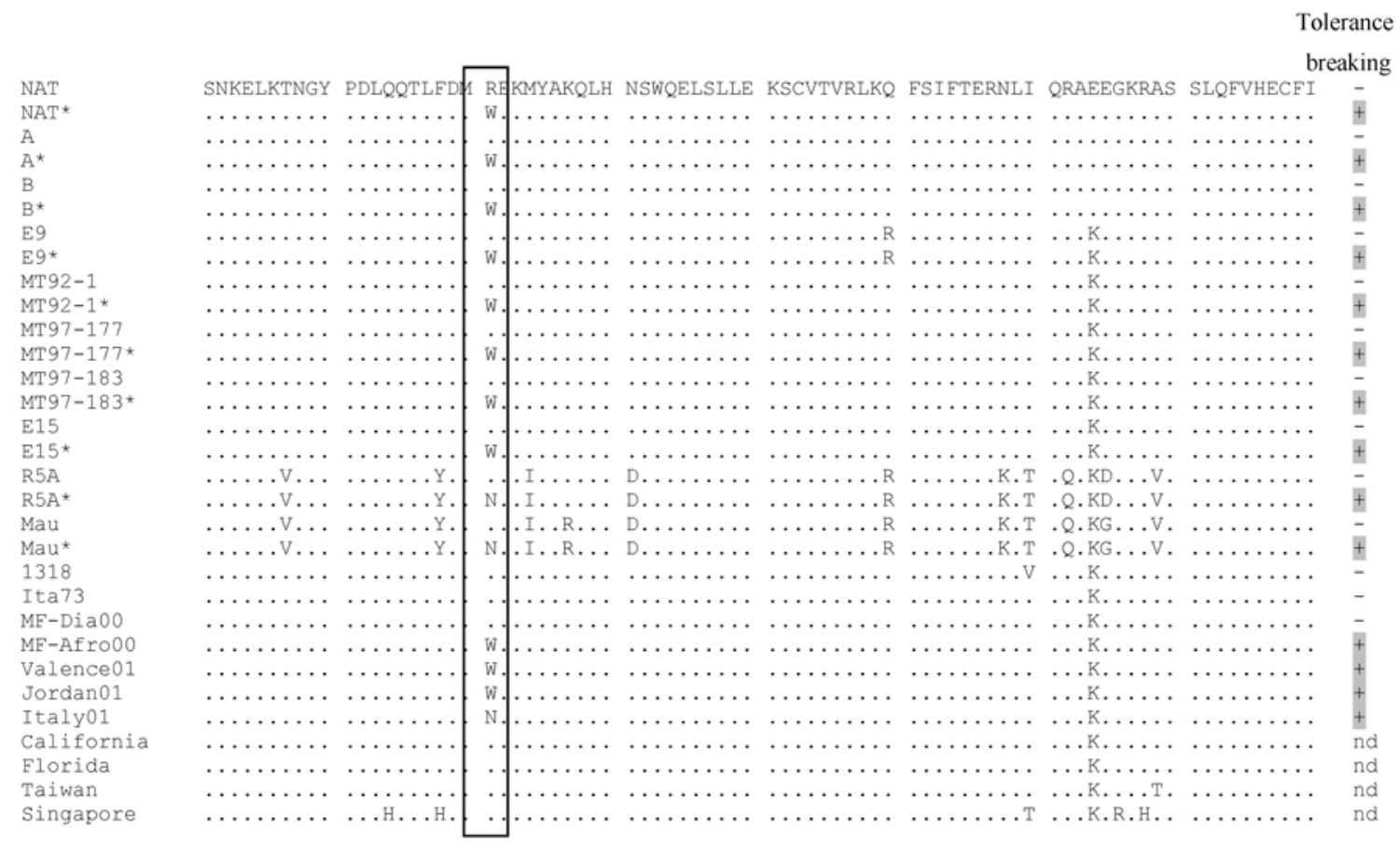

Fig. 2. Partial amino-acid sequence alignment of the $\mathrm{P} 3$ protein of wild-type and aggressive Zucchini yellow mosaic virus strains. Aggressive variants are noted with an asterisk $\left(^{*}\right)$ after the name of the isolate from which they evolved; - = wild-type strain (no symptoms or yellow leaf patches and slight mottle on tolerant cultivars); $+=$ tolerance-breaking strain (severe mosaics and deformations on tolerant cultivars); nd $=$ not determined.
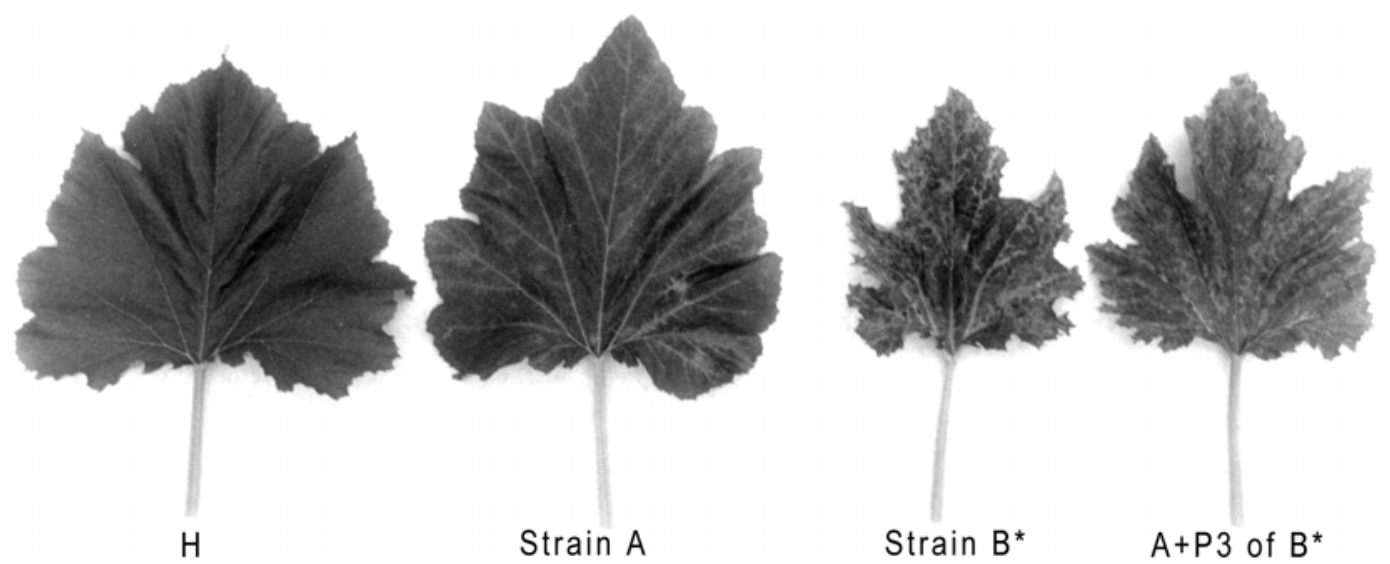

Fig. 3. Symptoms induced by Zucchini yellow mosaic virus (ZYMV)-A, ZYMV-B*, and a recombinant virus ZYMV-A containing the $\mathrm{R}_{917} \mathrm{~W}$ mutation of $\mathrm{B}^{*}$ in the $\mathrm{P} 3$ protein, on zucchini cv. Afrodite. $\mathrm{H}$, healthy control. 
pendent aggressive variants. So far, only mutations $\mathrm{R}_{917} \mathrm{~W}$ and $\mathrm{R}_{917} \mathrm{~N}$ were observed in natural conditions. Independent evolution experiments in greenhouse conditions with strains NAT and E15 or mutants A and B on cvs. Afrodite, Dividend, Sofia, and Tigress repeatedly led to the same mutations $\mathrm{R}_{917} \mathrm{~W}$ (AGG to $\mathrm{TGG}$ ) or $\mathrm{R}_{917} \mathrm{~N}$ (AGG to AAT). Aggressive variants seemed to appear at the same rate in all tolerant cultivars, and the mutations observed were identical (data not shown).

Recombinant clones of ZYMV-B containing the BamHI-NruI fragment of $\mathrm{A}^{*}$ or $\mathrm{B}^{*}$ were obtained and inoculated to zucchini plants. The only difference in the replaced fragment between ZYMV-B and $A^{*}$ or $B^{*}$ is the presence of mutation $R_{917} W$. Recombinant clones of $A$ containing the $\mathrm{R}_{917} \mathrm{~W}$ and $\mathrm{R}_{917} \mathrm{~N}$ mutations also were obtained the same way. All recombinant strains were infectious on Diamant and Afrodite and induced the same severe symptoms as $\mathrm{A}^{*}$ and $\mathrm{B}^{*}$ (Fig. 3). This confirms that the single amino acid alteration at position 917 within the P3 is responsible for the aggressiveness phenomenon.

Sequence comparison of $\mathrm{P3}$ protein between potyviruses. The P3 protein is known to be very variable between potyviruses (1). Twenty amino acid sequences corresponding to the P3 protein of 19 potyviruses were aligned with DAMBE (Fig. 4; data not shown). Ten residues, not including the $\mathrm{N}$-terminal $\mathrm{G}$ involved in the YXVG/G cleavage site of HC-Pro (4) and the C-terminal Q of the $\mathrm{P} 3 / 6 \mathrm{~K} 1$ cleavage site (32), were conserved among the viruses and strains included in the analysis. This conservation was partial

BCMV
BYMV
LMV
MDMV
PMOV
PSbMV
PStV
PepMoV
PPV
PRSV
PVA
PVY-HU
SMV
SPFMV
TEV
TVMV
TUMV
YMV
ZYMV-C
ZYMV-B+
Consensus
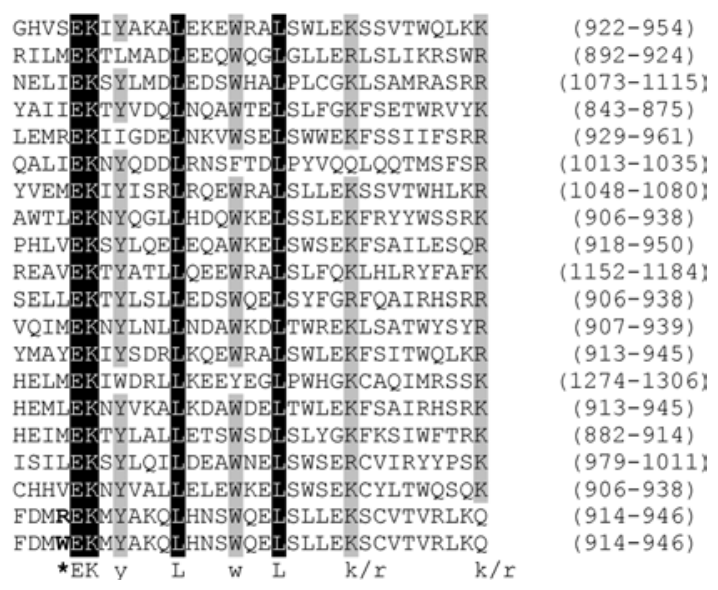

Fig. 4. Amino acid sequence alignment in the central part of the P3 protein from 20 Potyvirus strains and isolates. Virus and strain denominations are as in text. Black or gray boxes represent the totally or partially conserved amino acids, respectively. The asterisk indicates position 917 of the $\mathrm{R}$ to $\mathrm{W}$ mutation in Zucchini yellow mosaic virus (ZYMV)-A* and - $\mathrm{B}^{*}$. Figures in brackets indicate the amino acid numbering of the sequences compared. for non-Potyvirus members of the family Potyviridae (data not shown). All conserved amino acids were observed in the N-terminal or central part of the P3, while the C-terminal part of the protein varied greatly in size and sequence between viruses. Four conserved amino acids were included in a 15 -amino acid (aa) stretch in the central part of the protein that represents the most obviously conserved part of the P3. Although the $R_{917}$ aa in ZYMV is not conserved among potyviruses, it is contiguous to a strictly conserved EK sequence at the N-terminal extremity of the 15-aa stretch (Fig. 4). Preliminary analysis on the P3 protein did not reveal any particular structure in that region that forms putatively an $\alpha$-helix, and is not involved in the two putative transmembrane domains of the P3 (data not shown).

Fitness of wild-type ZYMV mutants and their aggressive variants on susceptible and tolerant zucchini squash cultivars in single or mixed infections. The $\mathrm{R}_{917} \mathrm{~W}$ mutation was the most frequently observed in aggressive variants obtained in greenhouse as well as in natural conditions; therefore, variants $\mathrm{A}^{*}$ and $\mathrm{B}^{*}$ containing this mutation were used for comparisons and for competition experiments with $\mathrm{A}$ and $\mathrm{B}$.

The virus concentrations estimated in ELISA for ZYMV A, B, $\mathrm{A}^{*}$, and $\mathrm{B}^{*}$ in single infections were not significantly different $(P>0.05)$ on susceptible as well as on tolerant plants (Fig. 5). Only mild symptoms were observed when A or B were inoculated to the tolerant cultivar; whereas, in the other virus-host combinations, the infected plants presented severe leaf mosaic and yellowing and important growth reduction, with leaf and fruit deformations.

In mixed infections, the accumulation of $\mathrm{A}^{*}$ and $\mathrm{B}^{*}$ in tolerant plants was not significantly reduced $(P>0.05)$ compared with single infections, whereas it dropped drastically for B and A, respectively $\left(P<10^{-4}\right)$, as measured in TAS-ELISA with specific MAbs (Fig. 5).

In susceptible plants, the opposite situation was observed: the accumulation of $\mathrm{A}$ and $\mathrm{B}$ presented no significant reduction $(P>$ $0.05)$, but the accumulation of $A^{*}$ and $B^{*}$ was drastically reduced in plants doubly infected with $\mathrm{B}$ and A, respectively (Fig. 5). Thus, although the tolerance-breaking variants $\mathrm{A}^{*}$ and $\mathrm{B}^{*}$ showed a much higher relative fitness than $\mathrm{A}$ and $\mathrm{B}$ in tolerant cv. Afrodite, they also presented a very important loss in relative fitness on ZYMV-susceptible hosts. The situation was perfectly symmetrical whether the mixed infections were with $\mathrm{A}$ and $\mathrm{B}^{*}$ or with B and $A^{*}$ (Fig. 5).

Relative fitness of ZYMV isolates on susceptible melon. In order to examine the fitness of the aggressive variants in different hosts, susceptible melons (Védrantais) were singly or doubly inoculated with $\mathrm{A}, \mathrm{B}, \mathrm{B}^{*}$, and $\mathrm{A}^{*}$. All infected plants presented the same typical ZYMV symptoms: yellowing and stunting, with severe leaf mosaic and deformations (data not shown).

The results obtained by ELISA were very similar to those observed on susceptible zucchini squash: $\mathrm{A}, \mathrm{A}^{*}, \mathrm{~B}$, and $\mathrm{B}^{*}$ presented

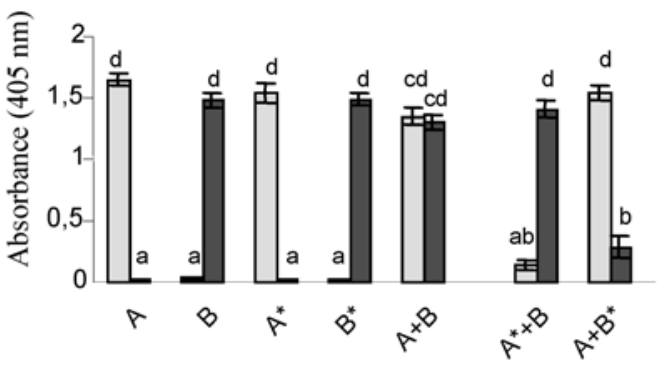

Diamant (susceptible)

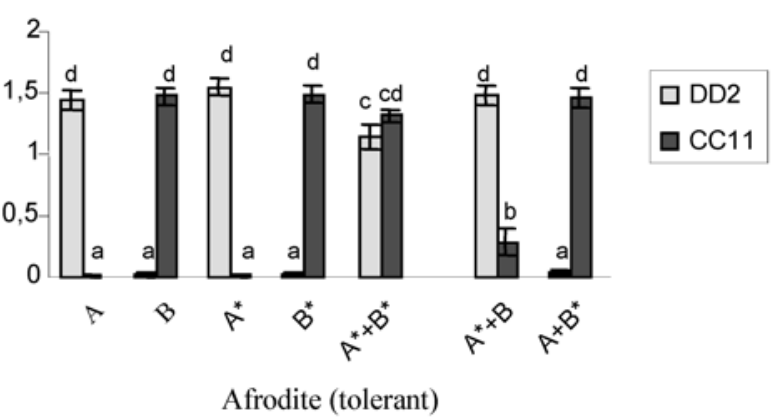

Fig. 5. Accumulation of Zucchini yellow mosaic virus strains $\mathrm{A}, \mathrm{A}^{*}, \mathrm{~B}$, and $\mathrm{B}^{*}$ in single or mixed infections of susceptible (Diamant) or tolerant (Afrodite) zucchini squash, measured in triple-antibody sandwich enzyme-linked immunosorbent assay with specific monoclonal antibodies DD2 and CC11, 2 weeks after mechanical inoculation. Mean of five independent repeats with five plants for each treatment. Error bars represent the standard error of the mean. Absorbance values associated with different letters, on Diamant and on Afrodite, are significantly $(P<0.05)$ different on the basis of Tukey's HSD test. 
high absorbances in ELISA that did not differ significantly $(P>0.05)$ in single infections, as well as in mixed infections of $\mathrm{A}+\mathrm{B}$ ) or $\mathrm{A}^{*}+\mathrm{B}^{*}$ (Fig. 6). In double infections of wild-type strain $\mathrm{A}$ or $\mathrm{B}$ with an aggressive variant $\mathrm{B}^{*}$ or $\mathrm{A}^{*}$, respectively, the aggressive variant accumulated significantly less $\left(P<10^{-4}\right)$, 2 and 4 weeks after inoculation, and could hardly be detected in ELISA (Fig. 6). The accumulation of the wild-type strains A and $\mathrm{B}$ was not significantly reduced compared with single infections (Fig. 6).

\section{DISCUSSION}

In this work we have identified the first determinant clearly associated with an enhanced virus aggressiveness in tolerant plants, and we provide a quantitative estimation of its effect on virus fitness in a competition situation. A single mutation within the P3 protein of ZYMV was sufficient to induce a total loss of the tolerance in zucchini squash. The fact that the $\mathrm{R}_{917}$ present in all wildtype strains could be encoded by different codons without difference in symptomatology, whereas all nonsilent mutations observed led to an increase in aggressiveness, suggests that the effect of the mutation is mostly at the protein level rather than at the RNA level. Aggressive mutants were obtained independently from ZYMV isolates belonging to the three main subgroups of ZYMV strains (10). All aggressive variants presented a point mutation affecting the same residue in the $\mathrm{P} 3$ protein, which may suggest a highly specific selection pressure in tolerant plants. Although previous works that assigned a role to the $\mathrm{P} 3+6 \mathrm{~K} 1$ in Potyvirus symptomatology have located symptom determinants in the highly variable $\mathrm{C}$-terminal part of the protein $(5,17,32,37)$, the $\mathrm{R}_{917}$ mutation in ZYMV is located in the less variable $\mathrm{N}$-terminal region of the P3, next to a stretch of relatively conserved amino acids. New data on P3 localization and putative functions are quite conflicting $(16,21,26,27,34)$; however, except for the first description of $\mathrm{P} 3$ protein that reported its presence in membrane fractions (35), no direct association of P3 with membranes has been observed so far $(21,34)$, in contradiction with computer analysis predictions that suggested the presence of two putative transmembrane domains in the $\mathrm{P} 3$ protein of potyviruses. In this work, the mutation present in aggressive ZYMV variants was not located in one of the putative transmembrane domains. The association of P3 with several viral proteins from the replication complex, as well as the loss of infectivity of insertion mutants in the P3 coding region (20), suggested a role of P3 in viral replication. $\mathrm{P} 3+6 \mathrm{~K} 1$ is also a pathogenicity determinant in the PSbMV-Pisum sativum cv. Bonneville gene-for-cistron interaction, affecting an early step in infection (19), and a point mutation in the C-terminal part of the P3 of TuMV induces a hypersensitive response in Brassica napus (17). Transgenic tobacco plants expressing the P3 protein of TVMV were chlorotic and developed poorly, suggesting a detrimental effect of $\mathrm{P} 3$ on the plants (28).

In the C. moschata Nigeria used as a source of resistance (33), wild-type strains as well as aggressive variants were detected serologically only in a few leaves just above the inoculated leaf, and they induced no symptoms or only a few chlorotic spots, even after serial passages (data not shown), indicating that a more efficient resistance mechanism was present in $C$. moschata which might have been partially lost during the interspecific crosses required for the transfer into the $C$. pepo genome. The mutation in ZYMV P3 protein seems to be involved mostly in the plantpathogen interactions leading to symptom expression, and not much in the virus replication or movement, because an effect on virus accumulation is detectable only in mixed infections. Thus, the selective constraints on the ZYMV-zucchini model might be different from what is usually considered for resistance.

One hypothesis for plant-virus coevolution in natural conditions suggests changes toward a reduced aggressiveness (36).
Tolerant crops usually are supposed to induce a much lower selection pressure on the pathogen than resistant ones (38), insuring a satisfying durability of the protection in field conditions. However, in the tolerant zucchini-ZYMV interaction, we observed the emergence of tolerance-breaking variants for all virus strains tested so far, either after mechanical inoculations or after aphid transmission. In natural conditions of aphid transmission, the emergence and spread of aggressive variants might even be enhanced by some aphid preference for symptom-expressing plants (11). Thus, the selection pressure for tolerance breaking seems to be as high as for resistance-breaking. ZYMV accumulates at high levels in tolerant cultivars, which may provide an important reservoir from which aggressive variants can emerge. Competition experiments showed that the relative fitness of aggressive variants in mixed infections was higher than that of wildtype strains, which correlates well with the frequent emergence of such variants.

Although the tolerance to ZYMV is easily broken, we revealed that the relative fitness of tolerance-breaking variants was reduced compared with wild-type virus in susceptible zucchini cultivars. Besides, even though the differences in symptomatology between variants were observed only on zucchini squash, the same loss of relative fitness of the aggressive variants was detected on a susceptible melon line, indicating that a general process in ZYMV pathogenicity, not complemented in trans by the nonaggressive strain in mixed infections, was somehow impaired by the single mutation in $\mathrm{P} 3$ protein.

Tolerance breaking involves a genetic cost for ZYMV in susceptible cucurbits; therefore, one would expect a disappearance of the evolved strains in susceptible hosts, as observed for a resistance-breaking mutant of TuMV (18). In preliminary experiments of sequential transfers to susceptible hosts from a susceptible plant with a mixed infection, a progressive decrease in the aggressive variant proportion in the population was observed (data not shown). In single infections of aggressive variants on susceptible hosts, a reversion to the wild-type virus with an " $\mathrm{R}$ " at position 917 (but encoded by a CGG codon instead of the AGG of the initial wild-type strain) also was observed for two out of three plants after three monthly passages (data not shown). No increase in relative fitness of the aggressive variants, related to compensatory mutations, was observed in singly or co-infected susceptible plants. Thus, the genetic cost for tolerance breaking remained high during the course of infections in the presence of wild-type variants, which could be a positive factor in terms of tolerance durability: the tolerance, even though easily overcome, could be "recycled" after a few production cycles of susceptible cultivars in the absence of tolerant plants.

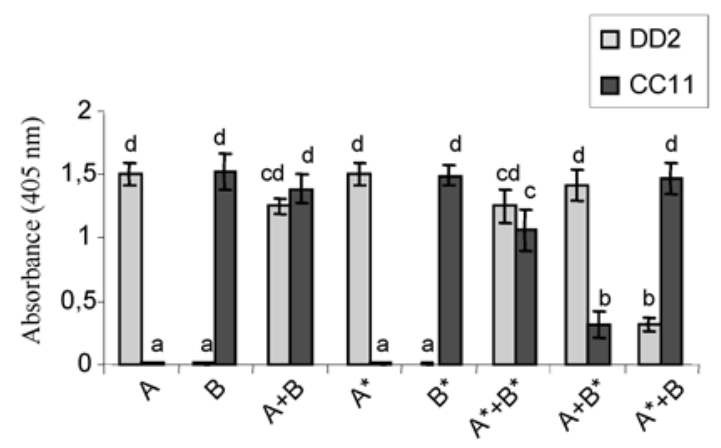

Fig. 6. Accumulation of Zucchini yellow mosaic virus strains A, A*, B, and $\mathrm{B}^{*}$ in single or mixed infections of susceptible melon Védrantais, measured in triple-antibody sandwich enzyme-linked immunosorbent assay with specific monoclonal antibodies DD2 and CC11, 2 weeks after mechanical inoculation. Mean of three independent repeats with five plants for each treatment. Error bars represent the standard error of the mean. Absorbance values associated with different letters are significantly $(P<0.05)$ different on the basis of Tukey's HSD test. 


\section{LITERATURE CITED}

1. Aleman-Verdaguer, M.-E., Goudou-Urbino, C., Dubern, J., Beachy, R. N., and Fauquet, C. 1997. Analysis of the sequence diversity of the P1, $\mathrm{HC}, \mathrm{P} 3, \mathrm{NIb}$ and $\mathrm{CP}$ genomic regions of several yam mosaic potyvirus isolates: Implications for the intraspecies molecular diversity of potyviruses. J. Gen. Virol. 78:1253-1264.

2. Antignus, Y., Raccah, B., Gal-On, A., and Cohen, S. 1989. Biological and serological characterization of zucchini yellow mosaic virus and watermelon mosaic virus-2 isolates in Israel. Phytoparasitica 17:289298.

3. Cardin, L., Devergne, J.-C., and Pitrat, M. 1984. Enzyme-linked immunosorbent assay of cucumber mosaic virus. I. Methodological aspect. Agronomie 4:125-135.

4. Carrington, J. C., and Herndon, K. L. 1992. Characterization of the potyviral HC-Pro autoproteolytic cleavage site. Virology 187:308-315.

5. Chu, M., Lopez-Moya, J. J., Llave-Correas, C., and Pirone, T. P. 1997. Two separate regions in the genome of the tobacco etch virus contain determinants of the wilting response of tabasco pepper. Mol. PlantMicrobe Interact. 10:472-480.

6. Cuff, J. A., and Barton, G. J. 1999. Evaluation and improvement of multiple sequence methods for protein secondary structure prediction. Proteins 34:508-519.

7. Desbiez, C., Gal-On, A., Raccah, B., and Lecoq, H. 1997. Characterization of epitopes on zucchini yellow mosaic potyvirus coat protein permits studies on the interactions between strains. J. Gen. Virol. 78:2073-2076.

8. Desbiez, C., and Lecoq, H. 1997. Zucchini yellow mosaic virus. Plant Pathol. 46:809-829.

9. Desbiez, C., Wipf-Scheibel, C., Granier, F., Robaglia, C., Delaunay, T., and Lecoq, H. 1996. Biological and molecular variability of zucchini yellow mosaic virus in the island of Martinique. Plant Dis. 80:203-207.

10. Desbiez, C., Wipf-Scheibel, C., and Lecoq, H. 2002. Biological and serological variability, evolution and molecular epidemiology of Zucchini yellow mosaic virus (ZYMV, Potyvirus) with special reference to Caribbean islands. Virus Res. 85:5-16.

11. Fereres, A., Kampmeier, G. E., and Irwin, M. E. 1999. Aphid attraction and preference for soybean and pepper plants infected with Potyviridae. Ann. Entomol. Soc. Am. 92:542-548.

12. Gal-On, A., Antignus, Y., Rosner, A., and Raccah, B. 1991. Infectious in vitro RNA transcripts derived from cloned cDNA of the cucurbit potyvirus, zucchini yellow mosaic virus. J. Gen. Virol. 72:2639-2643.

13. Gal-On, A., Antignus, Y., Rosner, A., and Raccah, B. 1992. A zucchini yellow mosaic virus coat protein gene mutation restores aphid transmissibility but has no effect on multiplication. J. Gen. Virol. 73:21832187

14. Gal-On, A., Meiri, E., Elman, C., Gray, D., and Gaba, V. 1997. Simple hand-held devices for the efficient infection of plants with viralencoding constructs by particle bombardment. J. Virol. Methods 64:103110.

15. Gal-On, A., Meiri, E., Huet, H., Hua, W. J., Raccah, B., and Gaba, V. 1995. Particle bombardment drastically increases the infectivity of cloned DNA of zucchini yellow mosaic potyvirus. J. Gen. Virol. 76:3223-3227.

16. Guo, D., Rajamäki, M.-L., Saarma, M., and Valkonen, J. P. T. 2001. Towards a protein interaction map of potyviruses: Protein interaction matrixes of two potyviruses based on the yeast two-hybrid system. J. Gen. Virol. 82:935-939.

17. Jenner, C., Tomimura, K., Ohshima, K., Hughes, S. L., and Walsh, J. A. 2002. Mutations in Turnip mosaic virus P3 and cylindrical inclusion proteins are separately required to overcome two Brassica napus resistance genes. Virology 300:50-59.
18. Jenner, C. E., Wang, X., Ponz, F., and Walsh, J. A. 2002. A fitness cost for Turnip mosaic virus to overcome host resistance. Virus Res. 86:1-6.

19. Johansen, I. E., Lund, O. S., Hjulsager, C. K., and Laursen, J. 2001. Recessive resistance in Pisum sativum and potyvirus pathotype resolved in a gene-for-cistron correspondence between host and virus. J. Virol. 75:6609-6614

20. Klein, P. G., Klein, R. R., Rodriguez-Cerezo, E., Hunt, A. G., and Shaw, J. G. 1994. Mutational analysis of the tobacco vein mottling virus genome. Virology 204:759-769.

21. Langenberg, W. G., and Zhang, L. 1997. Immunocytology shows the presence of Tobacco etch virus P3 protein in nuclear inclusions. J. Struct. Biol. 118:243-247.

22. Leach, J. E., Vera Cruz, C. M., Bai, J., and Leung, H. 2001. Pathogen fitness penalty as a predictor of durability of disease resistance genes. Annu. Rev. Phytopathol. 39:187-224.

23. Lecoq, H., and Pitrat, M. 1984. Strains of zucchini yellow mosaic virus in muskmelon (Cucumis melo L.). J. Phytopathol. 111:165-173.

24. Lecoq, H., and Purcifull, D. E. 1992. Biological variability of potyviruses, an example: Zucchini yellow mosaic virus. Arch. Virol. Suppl. 5:229-234.

25. Matthews, R. E. F. 1991. Plant Virology, 3rd edition. Academic Press, San Diego, CA.

26. Merits, A., Guo, D., Järvekülg, L., and Saarma, M. 1999. Biochemical and genetic evidence for interactions between potato A potyvirus-encoded proteins $\mathrm{P} 1$ and $\mathrm{P} 3$ and proteins of the putative replication complex. Virology 263:15-22.

27. Merits, A., Guo, D., and Saarma, M. 1998. VPg, coat protein and five non-structural proteins of potato A potyvirus bind RNA in a sequenceunspecific manner. J. Gen. Virol. 79:3123-3127.

28. Moreno, M., Bernal, J. J., Jimenez, I., and Rodriguez-Cerezo, E. 1998. Resistance in plants transformed with the P1 or P3 gene of tobacco vein mottling potyvirus. J. Gen. Virol. 79:2819-2827.

29. Munger, H. M., and Provvidenti, R. 1987. Inheritance of resistance to zucchini yellow mosaic virus in Cucurbita moschata. Cucurbit Genet. Coop. Ann. Rep. 10:80.

30. Paris, H. S., and Cohen, S. 2000. Oligogenic inheritance for resistance to zucchini yellow mosaic virus in Cucurbita pepo. Ann. Appl. Biol. 136:209-214.

31. Revers, F., Le Gall, O., Candresse, T., and Maule, A. J. 1999. New advances in understanding the molecular biology of plant/potyvirus interactions. Mol. Plant-Microbe Interact. 12:367-376.

32. Riechmann, J. L., Cervera, M. T., and Garcia, J. A. 1995. Processing of the plum pox virus polyprotein at the P3-6K1 junction is not required for virus viability. J. Gen. Virol. 76:951-956.

33. Robinson, R. W., and Provvidenti, R. 1997. Differential response of Cucurbita pepo cultivars to strains of Zucchini yellow mosaic virus. Cucurbit Genet. Coop. Rep. 20:58-59.

34. Rodriguez-Cerezo, E., Ammar, E. D., Pirone, T. P., and Shaw, J. G. 1993. Association of the non-structural P3 viral protein with cylindrical inclusions in potyvirus-infected cells. J. Gen. Virol. 74:1945-1949.

35. Rodriguez-Cerezo, E., and Shaw, J. G. 1991. Two newly detected nonstructural viral proteins in potyvirus-infected cells. Virology 185:572-579.

36. Roy, B. A., and Kirchner, J. W. 2000. Evolutionary dynamics of pathogen resistance and tolerance. Evolution 54:51-63.

37. Saenz, P., Cervera, M. T., Dallot, S., Quiot, L., Quiot, J.-B., Riechmann, J. L., and Garcia, J. A. 2000. Identification of a pathogenicity determinant of Plum pox virus in the sequence encoding the C-terminal region of protein P3+6K1. J. Gen. Virol. 81:557-566.

38. Salomon, R. 1999. The evolutionary advantage of breeding for tolerance over resistance against viral plant diseases. Israel J. Plant Sci. 47:135-139.

39. Xia, X. 2000. Data Analysis in Molecular Biology and Evolution. Kluwer Academic Publishers, Boston. 